HortSCIENCE 26(1):77-78. 1991.

\title{
Gy 5 Cucumber Inbred and 'Johnston' Hybrid Pickling Cucumber
}

Todd C. Wehner ${ }^{1}$ and Samuel F. Jenkins, Jr. ${ }^{2}$

North Carolina State University, Raleigh, NC 27695-7609

\section{Richard L. Lower ${ }^{3}$}

University of Wisconsin, Madison, WI 53706

Additional index words. Cucumis sativus, vegetable breeding

Gy 5 is a multiple disease-resistant, gynoecious cucumber (Cucumis sativus L.)

Received for publication 5 Sept. 1989. The use of trade names in this publication does not imply endorsement by the NCARS of the products named, nor criticism of similar ones not mentioned. Research funded in part by a grant from the North Carolina Pickle Producers Assn. We gratefully acknowledge the technical assistance of R.R. Horton, Jr. and J.C. Mather. The cost of publishing this paper was defrayed in part by the payment of page charges. Under postal regulations, this paper therefore must be hereby marked advertisement solely to indicate this fact.

'Professor of Horticultural Sciences.

${ }^{2}$ Professor of Plant Pathology (deceased).

${ }^{3}$ Professor of Horticulture. inbred. It has high combining ability for multiple harvest yield, producing high-yielding hybrids when crossed to monoecious inbred lines. In addition, it has a high level of resistance to anthracnose (Colletotrichum orbiculare) under North Carolina field conditions.

Gy 5, in hybrid combination with the monoecious inbred, NCSU M 21, makes the hybrid 'Johnston'. 'Johnston' has about the same yield (\$/ha) as 'Regal', a popular, longfruited cultivar in North Carolina (Table 1). Fruit quality (shape, color, and seed cell size), length : diameter ratio, firmess, bloater resistance, and early yield were about the same for 'Johnston' as for 'Regal'. Anthracnose resistance for 'Johnston' is higher than in 


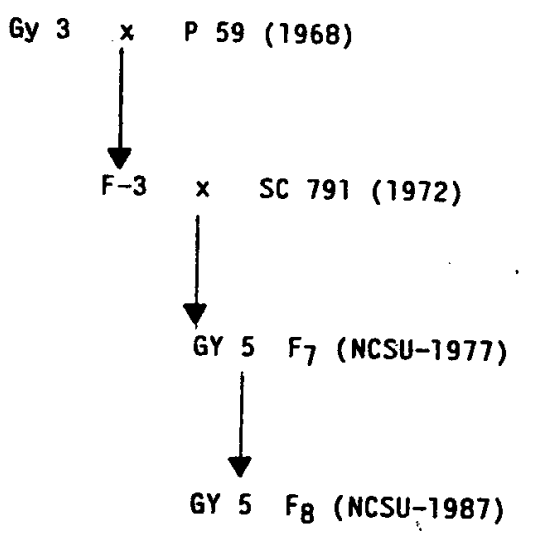

Fig. 1. History of breeding and development of Gy 5.

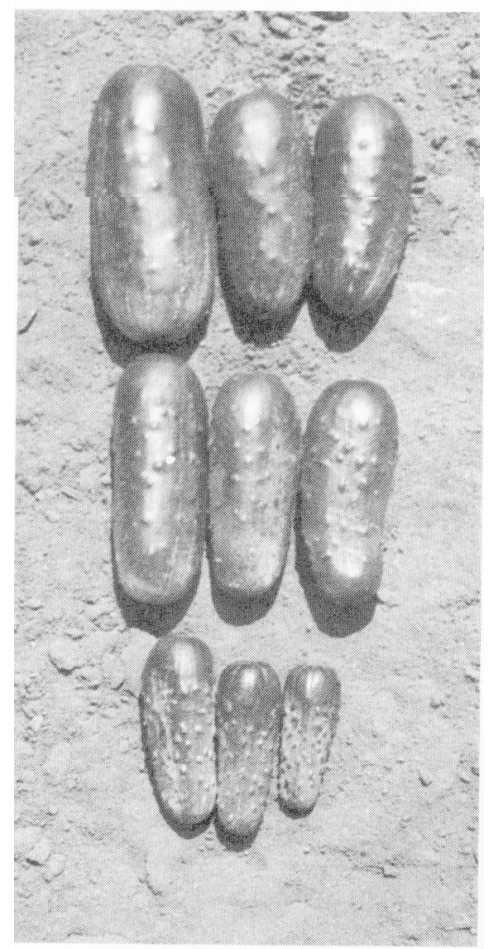

Fig. 2. Typical fruits of Gy 5 pickling cucumber inbred.

cultivars with moderate resistance like 'Carolina' and 'Regal' .

\section{Origin}

Gy 5 originated from the cross of the multiple disease-resistant gynoecious inbred SC 791 with the high fruit quality inbred NCSU Gy 1 (Fig. 1). Segregating populations were tested for disease resistance in the seedling

Table 1. Performance of 'Johnston' hybrid (Gy $5 \times \mathrm{M} 21$ ) compared with a set of standard pickling cucumber cultivars for the southeastern United States.

\begin{tabular}{lccccccc}
\hline \hline Cultivar & $\begin{array}{c}\text { Yield } \\
(\$ / \mathrm{ha})\end{array}$ & $\begin{array}{c}\text { Earliness } \\
(\$ / \mathrm{ha})\end{array}$ & $\begin{array}{c}\text { Quality } \\
1-9\end{array}$ & $\begin{array}{c}\text { Anthracnose } \\
0-9\end{array}$ & $\begin{array}{c}\text { Fir m n e s s } \\
(\mathrm{kg})\end{array}$ & $\begin{array}{c}\text { L : D } \\
\text { ratio }\end{array}$ & $\begin{array}{c}\text { Balloon } \\
(\%)\end{array}$ \\
\hline Johnston & 4610 & 1740 & 6.8 & 3.4 & 8.6 & 3.4 & 3 \\
Explorer & 3710 & 1380 & 6.2 & 4.4 & 9.1 & 2.9 & 4 \\
Carolina & 3980 & 1590 & 6.3 & 4.8 & 9.1. & 3.0 & 5 \\
Calypso & 4310 & 1640 & 6.3 & 3.8 & 9.1 & 3.1 & 3 \\
Regal & 4960 & 1740 & 5.6 & 4.4 & 8.2 & 3.2 & 3 \\
LSD (5\%) & $519 "$ & 393 & 1.0 & 0.9 & 0.5 & 0.1 & 2 \\
\hline
\end{tabular}

${ }^{2}$ Data are means over 3 years $(1983,1984,1985)$, two seasons (spring, summer) and three replications. Yield data are summed over six harvests. Dollar values based on North Carolina processor prices for grades one through four. Earliness is the yield in harvests one and two. For quality, $1=$ poor, $9=$ excellent; for anthracnose, $0=$ no disease, $9=$ plant dead. Firmness is the force required to punch a hole in 45-mm-diameter fruits (10-fruit samples) with a Magness-Taylor tester having an 8-mm tip. L : $\mathrm{D}$ is the length : diameter ratio of $35-\mathrm{mm}$-diameter fruits (10-fruit samples). Balloon is the percentage of the fruit tissue damaged by balloon bloating in a brine tank purged with $100 \% \mathrm{CO}_{2}$ gas.

Table2. Diseases for which Gy 5 has been evaluated in field and greenhouse tests.

\begin{tabular}{|c|c|c|c|}
\hline Pathogen & Common name & Test $^{2}$ & Reaction $^{y}$ \\
\hline Cladosporium сисumerinum En. \& Arth. & Scab (spot rot) & $\mathrm{GH}$ & $\mathrm{R}$ \\
\hline Cucumber mosaic virus & $\mathrm{CMV}$ & GH & $\mathrm{M}$ \\
\hline Pseudomonas sryinge pv. lachrymans (Smith & & & \\
\hline $\begin{array}{l}\text { \& Bryan) Young et al. } \\
\text { Colletotrichum orbiculare (Berk. \& Mont.) }\end{array}$ & Angular leafspot & GH & $\mathrm{R}$ \\
\hline von Arx & Anthracnose & $\mathrm{GH}+\mathrm{F}$ & $\mathrm{R}$ \\
\hline Pseudoperonospora cubensis (Berk. \& Curt.) & & & \\
\hline Rostow & Downy mildew & $\mathrm{GH}$ & $\mathrm{R}$ \\
\hline $\begin{array}{l}\text { Sphaerotheca fuliginea (Schlecht.: Fr.) Poll. } \\
\text { Fusarium oxysporum (Schlecht.) }\end{array}$ & Powdery mildew & $\mathrm{GH}$ & $\mathrm{R}$ \\
\hline Snyd. \& Hans. f. sp. cucumerinum Owen & Fusarium wilt & & $\mathrm{R}$ \\
\hline Didymella bryoniae (Auersw.) Rehm & Gummy stern blight & $\mathrm{F}$ & I \\
\hline Rhizoctonia solani Kuhn & Belly rot & $\mathrm{F}$ & I \\
\hline
\end{tabular}

${ }^{2}$ Tests were on mature plants in the field $(\mathrm{F})$ or on seedlings in the greenhouse $(\mathrm{GH})$

${ }^{y}$ Hostreaction was resistant (R), moderately resistant (M), or intermediate (I).

stage, and for yield, earliness, quality, gynoecious expression, bloater resistance, and disease resistance in the field. Lines inbred to the $\mathrm{F}_{8}$ were tested for disease resistance and gynoecious expression before being selected for final increase. Final increase was made by self-pollinating a single $\mathrm{F}_{8}$ plant in the greenhouse and then intercrossing the resulting $\mathrm{F}_{\mathrm{g}}$ progeny in an isolation block in the greenhouse.

\section{Description}

Vines. Gy 5 has moderately long, medium-green vines with an indeterminate branched plant habit. Leaves are medium size. Vine growth is vigorous under hot, humid conditions common to the spring and summer production seasons of the southeastern United States, and in the Midwest.

Flowering habit. The plants are gynoecious, nonparthenocarpic, and reach $50 \%$ flowering when plants are $\approx 30$ days old (when grown under controlled 30/20C day/night conditions). Flowering is sequential and usually begins at the first node.

Fruits. Gy 5 is a pickling cucumber with medium-long, light green fruits, and white spines (Fig. 2). The fruits are coarse-spined (moderately warted), and have a slight speckling and striping (not uniform green). Gy 5 has a length : diameter (L : D) ratio of 3.1 for 35-mm-diameter fruits.

Resistance. Gy 5 has field resistance to seven diseases common in the United States (Table 2): scab, cucumber mosaic virus, downy mildew, powdery mildew, anthracnose, angular leaf spot, and fusarium wilt. It has moderate tolerance to gummy stem blight and Rhizoctonia fruit rot. Gy 5 is susceptible or untested for reaction to target leaf spot, bacterial wilt, zucchini yellows mosaic virus, and watermelon mosaic virus.

\section{Availability}

Small amounts of breeder's seed may be obtained from T.C.W. 